\title{
The Effect of Self-Assessment with Inquiry Learning Model to Self-Efficacy and Physics Learning Outcomes
}

\author{
Ni Ketut Rapi ${ }^{1, *}$ Putu Widiarini ${ }^{1}$ I Wayan Suastra $^{1}$ \\ ${ }^{1}$ Physics Education Study Program, Universitas Pendiidkan Ganesha, Singaraja, Indoensia \\ ${ }^{*}$ Corresponding author.Email: ketutrapi658@gmail.com
}

\begin{abstract}
The main aim of this research was to determine the differences in self-efficacy and physics learning outcomes between students who were facilitated by self-assessment with inquiry learning model and students who were facilitated by conventional assessments. This study used a posttest only non-equivalent control group design. The sample was 16 students of the second semester of the physics education study program, FMIPA Universitas Pendidikan Ganesha that was divided into two equivalent groups determined by random. The used instrumentswere the self-efficacy questionnaire and physics learning outcome test in the essay form. The reliability of the self-efficacy questionnaire and the physics learning outcome test were 0.81 and 0.76 , respectively. The data collected were analyzed using descriptive and multivariate analysis. The results showed that: (1) the average value of self-efficacy in the experimental group was 82.6 with a standard deviation of 6.1 in the high category and 73.9 in the control group with a standard deviation of 3.4 in the high category. (2) the average value of physics learning outcomes in the experimental group is 80.0 with a standard deviation of 10.5 in the high category and the control group is 65.2 with a standard deviation of 12.0 in the moderate category; and (3) there are differences in self-efficacy and physics learning outcomes between students who are facilitated by self-assessment with inquiry learning model and those facilitated by conventional assessments. This means that self-assessment with inquiry learning model has a better influence on the achievement of self-efficacy and student physics learning outcomes.
\end{abstract}

Keywords: inquiry, self-assessment, self-efficacy, physics learning outcomes

\section{INTRODUCTION}

The objective of higher education is to develop students' potential to become capable, creative, and selfsufficient individuals, as well as to grasp science and technology. Based on the aims and principles of the law on higher education, it is implied that to face the demands of the times, students must be proficient in dealing with problems, be independent, master knowledge and technology, have self-efficacy, and other abilities. Quality education serves to improve abilities while also shaping the national character and civilization. In the era of industrialization and technology, the mastery of science and technology plays a very important role.

Learning is not as a dream for the future but as a fact, must carry out internal reforms and continuous improvement of the education system[1]. Preliminary studies show that the hope for the growth of the creative and anticipatory nature of Physics teachers in learning practices to maximize the role of students today is still not optimal. This seems to occur from the lowest formal education bench to higher education. This is suspected as a contributing factor to the poor quality of physics learning processes and products.

21 st century learning requires students not only to have knowledge, but also to have the ability to think critically, creativity, character, to be able to use and express knowledge, and communicate. 21st century learning aims to prepare students to join the world of work which requires them to have high curiosity, problem solving, self-efficacy, and critical thinking[2]. The implementation of the 2016 curriculum in the Physics Education study program, Universitas Pendidikan Ganesha has not been able to maximize selfefficacy and student learning outcomes. As evidenced by the majority of students who are less convincing in conveying ideas during learning and student learning outcomes are also less than optimal.

The packaging of learning that has been carried out so far is not in line with the nature of people learning 
and the nature of people teaching according to the constructivist view. Learning that is carried out specifically for basicphysics courses tends to use the lecture and discussion method. Teaching means participation with learners in forming knowledge, making meaning, seeking clarity, being critical, and holding justifications[3].

In addition to the selection of learning models that are to the degree with the characteristic of course content and student characteristics, assessments also need to be carried out in accordance with the principles of assessment. So far, the assessment has only focused on the assessment of attitudes, assignments, midsemester exams, and end-of-semester exams. Selfassessment has never been done, this causes students to not know their strengths and weaknesses in learning. A new idea to overcome the lack of self-efficacy and student learning outcomes is to apply one formative assessment and integrate it with innovative learning models. This method is believed to be able to accommodate students to build their own knowledge through scientific discoveries and to reflect on their learning process. One alternative to formative assessment that is integrated with innovative learning models for enhancing one's self-efficacy and student learning outcomes is a self-assessment containing an inquiry learning model.

Based on the research background, the problems that will be answered through this research can be formulated as follows: 1) is there a difference in selfefficacy and physics learning outcomes simultaneously between students who were facilitated with selfassessment with inquiry learning model and students who were facilitated with conventional assessments?, 2) is there a difference in self-efficacy between students who were facilitated with self-assessment with inquiry learning model and students who were facilitated with conventional assessments?, and 3) is there a difference in learning outcomes between students who were facilitated with self-assessment with inquiry learning model and students who were facilitated with conventional assessments?.

The domain taxonomy consists of the cognitive domain, affective domain, and psychomotor domain[4]. There are two dimensions of cognitive learning outcomes, namely, knowledge and cognitive process which can be classified within the educational taxonomic framework[5]. Factual, conceptual, procedural, and metacognitive knowledge are all categories of knowledge defined by Anderson and Krathwohl. One of the factors that influence learning outcomes is Self-efficacy.

Self-efficacy is a person's belief in being able to organize and carry out the actions needed to achieve goals [6]. This self-confidence will affect how the thoughts, feelings, motivations, and actions of each individual. Developing a sense of self-efficacy can be aided by four different sources of information, including:: experiences about personal success (enactive mastery experiences), vicarious experiences, verbal persuasion and social rewards (verbal persuasion and other related experiences), social recognitions), and individual psychological and affective states[6]. Selfefficacy is an internal factor that affects student learning outcomes. Bandurareveals that there are three dimensions of self-efficacy, including the level dimension, generality dimension, and strength dimension. In addition to the self-efficacy factor, the type of formative assessment applied also affects learning outcomes.

Formative assessments are implemented for the purpose of monitoring to the fullest degree to which an educational process has been running as planned. With formative assessment, it is hoped that teachers can improve their teaching programs and implementation strategies. Assessment is a general term that is defined as a process taken to obtain information that is used in order to make decisions about students, curriculum, programs, and educational policies, institutions, organizations or official institutions that organize a program[7]. certain activity. One form of assessment is self-assessment. Self-assessment is an act of monitoring the level of one's own knowledge, learning, abilities, thoughts, actions and strategies used[8]. Characteristics of self-assessment is the involvement of students in identifying standards to be set in learning and making decisions about achieving these standards. Selfassessment as assessment as learning functions as a formative assessment carried out during the learning process. Self-assessment as a formative assessment has a number of principles that underlie the implementation of its assessment including: (a) formative assessment is integrated with ongoing learning activities; (b) involving students in its implementation, (c) regarding not only progress in mastering the domains of attitudes, knowledge, and skills, but also learning motivation, attitudes towards learning, learning styles, and cooperation in the learning process. Self-assessment has a positive impact on students, including: (1It can help students develop their self-esteem, (2) students are able to identify their strengths and limitations because in the assessment process they must introspect on their abilities, and (3) can encourage, familiarize and train students to be objective and honest.

Self-assessment can provide several advantages for students, namely: (1) students become more motivated, (2) students take greater responsibility for their own learning, (3) students are in charge of charting their own course of study, (4) have a good impact on students' self-esteem, and (5) students more actively engaged in the learning process. The function of self-assessment activities used in learning is the achievement of goals or mastery of competencies and self-correction of the process and achievement of learning outcomes. Selfassessment gives students the opportunity to be able to 
see their strengths and weaknesses, then these deficiencies become the goal of improvement. Thus, students are more responsible for the process and achievement of learning objectives.

Rolheiser \& Ross[9] propose a theoretical model to show the contribution of self-assessment to the achievement of goals which is described as follows. When self-assessing performance, students are encouraged to set higher goals. For that, students must make a harder effort. The combination of these objectives and efforts determines whether or not they are accomplished. Furthermore, these achievements result in self-judgment through contemplation of the goals that have been achieved. As a result, there is a self-reaction to what is felt from the achievement. To develop positive self-confidence, goals, effort, achievement, self-judgment, and self-reaction can all be blended. This demonstrates that self-evaluation is a combination of components that include self-judgment and self-reaction.

The self-assessment containing the inquiry learning model is a combination of the self-assessment and the inquiry learning model. The self-assessment containing the inquiry learning model applies formative assessment which is facilitated by the syntax of the inquiry learning model. The application of self-assessment containing the inquiry learning model is able to provide opportunities for students to be able to develop selfconfidence, critical thinking skills, free to express opinions, so as to improve student learning activities through assessing their strengths and weaknesses and collaborative learning with peers. Self-assessment occurs when students assess their own competencies to then determine improvement strategies in relation to the gaps found between the competencies they have and the competencies expected [10].

Applying the inquiry learning model in physics learning, self-assessment is carried out in an integrated manner. Through self-assessment students can plan and build their knowledge and monitor their progress. Through self-assessment students can see their strengths and weaknesses, so that these deficiencies become the goal of improvement. This causes students to be more responsible for their learning process and achieving their learning goals. Self-assessment is meaningful because students can feel their learning progress, feel they have greater autonomy, feel they are doing something useful for themselves, not just doing assignments from the lecturer.

The implementation of self-assessment in physics learning with an inquiry learning model is carried out in stages as shown in Table 1.

Table 1. The implementation of self-assessment in physics learning with an inquiry learning model

\begin{tabular}{|c|c|}
\hline Learning activities & $\begin{array}{l}\text { Self-assessment with inquiry learning } \\
\text { model activities }\end{array}$ \\
\hline $\begin{array}{l}\text { A.Opening activities } \\
\begin{array}{ll}\text { 1. } & \text { Giving opening greeting } \\
\text { 2. } & \text { Checking student attendance } \\
\text { 3. } & \text { Orienting students about today's learning }\end{array}\end{array}$ & $\begin{array}{l}\text { Agree on learning directions and targets } \\
\text { and scoring strategies }\end{array}$ \\
\hline $\begin{array}{l}\text { B.Core activities } \\
\text { 1. The Phase of Dealing with Problems } \\
\text { a. Asking questions or problems that can motivate students to } \\
\text { express their opinions, using prior knowledge } \\
\text { b. Assigning students to make hypotheses } \\
\text { c. Establish a hypothesis from the answer students for further } \\
\text { study }\end{array}$ & $\begin{array}{l}\text { Self-assessment with assessment aspects } \\
\text { Formulate a hypothesis }\end{array}$ \\
\hline $\begin{array}{l}\text { 2. The phase of collecting information } \\
\text { a.Assigning students to look for information related to the problem } \\
\text { they face. }\end{array}$ & $\begin{array}{l}\text { Self-assessment with assessment aspects: } \\
\text { how to find information and completeness of } \\
\text { information }\end{array}$ \\
\hline $\begin{array}{l}\text { 3. The phase of colleting data in experiment } \\
\text { a. Assign students to design and conduct virtual experiments } \\
\text { b. Guiding the experimental process by answering questions and } \\
\text { directing students to test hypotheses through guiding questions. }\end{array}$ & $\begin{array}{l}\text { Self-assessment with assessment aspects: } \\
\text { measuring assessment, identifying } \\
\text { variables, conducting experiments }\end{array}$ \\
\hline
\end{tabular}




\begin{tabular}{|l|l|}
\hline \multicolumn{1}{|c|}{ Learning activities } & \multicolumn{1}{c|}{$\begin{array}{c}\text { Self-assessment with inquiry learning } \\
\text { model activities }\end{array}$} \\
\hline $\begin{array}{l}\text { 4. The phase of formulation } \\
\text { a. Through class discussions, the lecturer assigns students } \\
\text { to come up with conclusions that they get. }\end{array}$ & $\begin{array}{l}\text { Self-assessment with assessments } \\
\text { aspects: data interpretation assessment, } \\
\text { using numbers and communicating }\end{array}$ \\
\hline $\begin{array}{l}\text { 5. The phase of applied concept } \\
\text { a. Assigning students to apply concept to solve physics }\end{array}$ & $\begin{array}{l}\text { Self-assessment with assessment } \\
\text { aspects: apply concept }\end{array}$ \\
\hline C.Closing activities & Assessment of learning outcomes: \\
2. Report collection & practicum reports \\
3. Giving closing greetings & \\
\hline
\end{tabular}

Conventional assessment is an assessment system commonly used by lecturers in the learning process so far. Conventional assessments function as formative assessments that are carried out during the learning process and are integrated with learning activities. The formative assessment carried out so far is giving a quiz in the form of a test in the form of an essay at the end of the lesson. Reflection and follow-up of the assessment are rare. This assessment focuses more on the assessment of the cognitive domain, as a result the assessment cannot be carried out as a whole. Conventional assessment presents problems or physics questions to students after they are given information about learning materials that are considered less constructivist. The responsibility of students towards learning and learning outcomes becomes small. This is because students learn only because the lecturer gives assignments to study the teaching material. This will reduce the independence of students in learning. Assessment is only carried out by lecturers. It does not give pupils any opportunities to develop the ability to find out their strengths and weaknesses in learning. Opportunities for students to engage in learning activities that are customized to their needs, talents, and interests, as well as opportunities for self-reflection through self-assessments and feedback, are scarce in traditional assessments. [9]. Learning with conventional assessments tends to be oriented towards solving practice questions that only contain calculations. This condition is very likely to make students only focus on solving problems instantly without having to understand much. The impact is that students will learn only when given assignments according to what was taught in the previous class.

\section{METHODS}

This study employed a non-equivalent control group design with posttest only. The total population is 17 students. The 16 students as sample were determined by random assignment. This study uses an independent variable in the form of formative assessment which consists of two dimensions, namely self-assessment containing inquiry learning models and conventional assessments. The dependent variable in this study is self-efficacy and physics learning outcomes. Selfefficacy instruments in the form of questionnaires and physics learning outcomes instruments in the form of essay tests. Descriptive statistics and multivariate analysis were used to analyze the data collected.

\section{RESULT AND DISCUSSION}

Based on the posttest result obtained the general description of the research data as shown in Table 2 . The mean of self-efficacy per dimension is shown in Table 3. The summary of Manova testing is shown in Table 4. The results of the multivariate test on selfefficacy and physics learning outcomes, students who were facilitated by the self-assessment with inquiry learning model and conventional assessment resulted in a significance number $=0.016$ on the $F$ value of Pillai's Trace, Wilks, Lambda, Hotelling's Trace, and Roy's Largest Root $=5.790 \mathrm{~b}$. Based on the results of the analysis, it shows that the null hypothesis is rejected. So, there are differences in the results of learning physics and self-efficacy together between students who were facilitated by self-assessment with an inquiry learning model and students who were facilitated by conventional assessments. The summary of between subject effect testing for testing hypothesis 2 and hypothesis 3 is shown in Table 5 .

Based on data in the Table 5, the F value of self-efficacy is 6.912 with significance of 0.02 . It shows that the null hypothesis is rejected. It is meant that there is a difference in self-efficacy between students who were facilitated by self-assessment with an inquiry learning model and students who were facilitated by conventional assessments. Based on the data analysis of physics learning outcomes, the $\mathrm{F}$ value is 12.45 with 
significance of 0.003 . it shows that the null hypothesis is rejected.

Table 2. The general description ofself-efficacyand physics learning outcomes

\begin{tabular}{|c|c|c|c|c|}
\hline \multirow{2}{*}{ Statistic } & \multicolumn{2}{|c|}{ Experimental group } & \multicolumn{2}{c|}{ Control group } \\
\cline { 2 - 5 } & Self-efficacy & Learning outcomes & Self-efficacy & Learning outcomes \\
\hline Mean & 82.6 & 80.0 & 73.9 & 65.2 \\
\hline SD & 6.1 & 10.5 & 3.4 & 12.0 \\
\hline Qualification & High & High & High & Moderate \\
\hline
\end{tabular}

Table 3. The mean of self-efficacy per dimension

\begin{tabular}{|c|c|c|c|c|}
\hline \multirow{2}{*}{$\begin{array}{c}\text { Dimension of } \\
\text { self-efficacy }\end{array}$} & \multicolumn{2}{|c|}{ Experiment group } & \multicolumn{2}{c|}{ Control group } \\
\cline { 2 - 5 } & Mean & Qualification & Mean & Qualification \\
\hline Level of self-efficacy & 81 & High & 75 & High \\
\hline Generality of self-efficacy & 84 & High & 74 & High \\
\hline Strength of self-efficacy & 83 & High & 72 & High \\
\hline
\end{tabular}

Table 4. The summary of Manova testing

\begin{tabular}{|c|l|r|r|}
\hline \multirow{2}{*}{ Effect } & \multicolumn{1}{|c|}{ Statistic } & F & Sig. \\
\hline \multirow{4}{*}{ Assessment } & Pillai's Trace & $5.790^{\mathrm{b}}$ & 0.016 \\
\cline { 2 - 4 } & Wilks'Lambda & $5.790^{\mathrm{b}}$ & 0.016 \\
\cline { 2 - 4 } & Hotelling's Trace & $5.790^{\mathrm{b}}$ & 0.016 \\
\cline { 2 - 4 } & Roy's Largest Root & $5.790^{\mathrm{b}}$ & 0.016 \\
\hline
\end{tabular}

Tabel 5. The summary of between subject effect testing

\begin{tabular}{|l|l|r|r|}
\hline Source & Dependent Variable & F & Sig. \\
\hline \multirow{2}{*}{ Type of assessment } & Self-efficacy & 6.912 & 0.020 \\
\cline { 2 - 4 } & Physics learning outcomes & 12.448 & 0.003 \\
\hline
\end{tabular}

So, there is distinction in physics learning outcomes between students who were facilitated by selfassessment with inquiry learning models and students who were facilitated by conventional assessments. The primary goal of this research was to obtain an overview of the effect of self-assessment with inquiry learning model in physics learning on students' self-efficacy and physics learning outcomes. The results show that selfassessment with the inquiry earning model had a significant effect on students' self-efficacy and physics learning outcomes. The results of descriptive analysis and testing of the three research hypotheses can be explained as follows. First, the results of the descriptive analysis show that 1 ) there are differences in the average value of self-efficacy between the experimental group and the control group, 2) the The experimental group's average self-efficacy score is 82.6, with a standard deviation of 6.1 , and 3 ) the average value of selfefficacy in the control group is 73.9 with a standard deviation of 3.4. Second, Descriptive analysis indicate that physics learning outcomes can be described as follows: 1) there are differences in the average value of physics learning outcomes between the experimental group and the control group, 2) with a standard deviation of 10.5 points, the average value of the experimental group's physics learning outcomes is 80.0 points, and 3) the average value of the control group's physics learning outcomes is 65.2 with a standard deviation of 12.0. This proves that students who were guided by self-assessment using the inquiry learning model had a better average value of physics learning outcomes than students who were assisted by conventional assessments.

Third, according to analysis results of each dimension of students'self-efficacy shows that 1) in the level of selfefficacy dimension, the average value for the experimental group is 81 , which is higher than the average value for the control group, which is 75,2 ) the average value of the experimental group is 84 , higher 
than control group is 74 in the generality of self-efficacy dimension, and 3) the average value of the experimental group is 83 , higher than control group is 72 in the strength of self-efficacy dimension. It means that selfassessment with the inquiry earning model is better than conventional assessments to develop each student's selfefficacy dimension.

Fourth, the first hypothesis testing showed that an Fcount value of 5.790 with a significanceof 0.016 . So, the null hypothesis was rejected. It states that the selfefficacy and physics learning outcomes of students who were facilitated by self-assessment with the inquiry learning model are higher than students who facilitated by conventional assessments simultaneously. Theoretically, these findings indicate that learning physics with self-assessment containing the inquiry learning model has a positive effect on self-efficacy and student physics learning outcomes. That is, self-efficacy and student physics learning outcomes are influenced by the type of physics learning assessment. The learning process tends to follow the type of assessment applied. If the assessment used requires an understanding of the concept, the learning process carried out is also based on understanding the concept. Student interaction in learning also adjusts to the demands of the assessment. Student learning outcomes are largely determined by their interactions in the learning process. Learning physics with self-assessment containing the inquiry learning model will increase students' self-efficacy, then learning outcomes will also increase in contrast to learning physics with conventional assessments which do not require the development of students' self-efficacy in learning.

Students' ability to tailor their learning activities to their unique needs, abilities, and interests, as well as opportunities for self-reflection through self-evaluation and feedback, cannot be acquired by conventional assessments.[9]. Even though, these chances provide a wealth of opportunities for these pupils to improve their academic performance. The assessment is widely utilized throughout the world due to its time and cost effectiveness. Assignments and student achievement are frequently overlooked and not seen as a more significant form of alternative assessment. The conventional assessment method is incapable of determining students' actual ability since it concentrates exclusively on a few characteristics and does not create opportunity for pupils to demonstrate their unique abilities and capabilities.

The findings of this study are empirically corroborated by those of $\mathrm{Zi}$ Yan's research. which concluded that students' physics learning outcomes assessed by self-assessment were higher than students' physics learning outcomes assessed by conventional assessments[11]. The findings of this study also supported by Stavros' findings that low-achieving pupils who participate in mobile- and computer-based selfassessments significantly improve their learning achievement.[12]. The beneficial effect of computer and mobile device use in education also enhances students' motivation to learn. It has the potential to be a viable alternative to paper and pencil-based evaluations.

Fifth, the second hypothesis testing resulted in an Fcount value of 6.912 with a significance of 0.020 . So, the null hypothesis was rejected. It states that the selfefficacy of students who were facilitated by selfassessment with an inquiry learning model is higher than students who were facilitated by conventional assessments. Theoretically, the findings of this study prove that self-assessment with the inquiry learning model in physics learning has a beneficial impact on student self-efficacy. The positive influence of selfassessment with the inquiry learning model on selfefficacy is caused by the characteristics of the selfassessment charged with the inquiry learning model itself. Self-assessment containing the inquiry learning model is an act of monitoring the level of one's own knowledge, learning, abilities, thoughts, actions and strategies used based on the inquiry process. Students self-assess in terms of the process and level of achievement of the acquired competencies. Selfassessment using the inquiry learning model is a process for assigning tasks to students in order to collect data on how far they have learnt on their own. Students are required to apply their knowledge and abilities in order to meet learning objectives in this exam. Selfassessment that incorporates the inquiry learning model is one of the assessments that teachers can use to observe and make judgments about what students know and can do during their learning. This assessment will also help teachers monitor student self-efficacy. Students' self-efficacy will be more developed with the application of self-assessment containing the inquiry learning model compared to conventional assessments. Through self-assessment containing the inquiry learning model, students are given the experience to discover concepts or principles of physics. Self-assessment containing the inquiry learning model gives students a lot of freedom to understand their own characteristics. With self-assessment as a form of assessment, students are required to learn according to their experience. They must organize themselves in order to have a good learning experience.

Empirically the results of this study are conforming to Kustijono that through the scientific process (inquiry) will train and provide control, ways of thinking, ability to manage time, honest behavior, critical problemsolving skills for students[13]. The results of this study are supported by Panadero, et. al.,which states that selfassessment gives students have the ability to assess 
themselves which will make them independent learners[14]. As an independent learner, you will continue to develop yourself on an ongoing basis. Additionally, it was indicated that the use of selfassessment can promote students' perseverance in learning physics, improve their skills, raise their learning independence, and increase their learning activity. It will be able to increase self-efficacy.

The last, the third hypothesis testing gave an F-count value of 12.448 with significance of 0.003 . So, the null hypothesis was rejected. It states that students who were assisted by self-assessment with an inquiry learning model achieved the same physics learning objectives as students who were supported by conventional assessments. The results of this study are in line with the opinion of Papanthymou\& Darra, namely selfassessment will contribute positively to increasing learning motivation, increasing academic achievement, developing independent learning, increasing self-esteem and improving learning quality[15]. Learning physics with self-assessment containing the inquiry learning model allows students to remain confident that they are able to solve the problems they face. With selfconfidence, students will be able to maintain and improve their physics learning outcomes. It is different from conventional assessment which does not provide guidance in learning. Conventional assessment emphasizes results and does not consider the process so that it has an impact on student readiness to take an exam.

Empirically the finding of this study are in line with the research conducted by Lisnawati\&Halimah, that There are disparities in the results of learning between the experimental and control groups. [16]. The learning outcomes of the experimental group were better than the control group. It can be seen that self-assessment can improve student learning outcomes. Students are trained in evaluating their own work. Self-assessment is carried out not limited to self-assessment without any improvement efforts. If it is carried out arbitrarily without providing clear guidance, direction and explanation of criteria then the results found can be invalid. Therefore, in self-assessment, students are given clear criteria in assessing, then give feedback on the results of the assessment. Through this self-assessment, they will be trained in finding their weaknesses and shortcomings. They can make repairs of their own accord. This means that conducting an assessment needs to be done planning, paying attention to the objectives and functions of the assessment, paying attention to the implementation of the assessment, success in planning, carrying out the assessment as a baseline in the learning process.

\section{CONCLUSION}

Based on the results and discussion, the conclusions of this research are follows. First, there is a significant difference in self-efficacy and physics learning outcomes together between students who were facilitated by self-assessment with an inquiry learning model and students who were facilitated by conventional assessments $(\mathrm{F}=5.790$; sig. $=0.016)$. Second, there is a significant difference in self-efficacy between students who were facilitated by a selfassessment with aninquiry earning model and students who were facilitated by conventional assessments $(\mathrm{F}=$ 6.9120 ; sig. $=0.020$ ). Third, there is a significant difference in physics learning outcomes between students who were facilitated by self-assessment with an inquiry learning model and students who were facilitated by conventional assessments $(\mathrm{F}=12.448$; sig. $=0.003$ ).

Self-assessment assisted by the inquiry learning model is one of the formative assessments combined with the syntax of the inquiry learning model. This assessment model can be an alternative formative assessment that can be applied in online and offline learning in an effort to achieve optimal students' selfefficacy and learning outcomes.

\section{ACKNOWLEDGMENTS}

Thanks to LPPM Universitas Pendidikan Ganesha for full support and funding for this research.

\section{REFERENCES}

[1] F. Edgar et al., Learning to be The World Education Today and Tomorrow. Offset Aubin, 1982.

[2] M. Fine and L. Desmond, "Inquiry-based learning: Preparing young learners for the demands of the ke-21st century," Educ. Voice, vol. 8, pp. 2-11, 2015.

[3] P. Suparno, Filsafat Konstruktivisme dalam Pendidikan. Kanisius, 1997.

[4] D. R. Krathwohl, B. S. Bloom, and B. B. Masia, Taxonomy of Educational Objectives: The Classification of Educational Goals. Handbook II: The Affective Domain. David McKay, 1973.

[5] L. W. Anderson and D. R. Krathwohl, $A$ Taxonomy for Learning Teaching Assessing. Longman, 2001.

[6] A. Bandura, Self-efficacy in Changing Societies. Cambridge University Press, 1995.

[7] A. J. Nitko, Educational Assesment of Students. Merril, 1995.

[8] J. Wilson and L. W. Jan, Self-Assessment for Students: Proformas and Guidelines. Eleanor Curtain Publishing, 1998.

[9] A. A. I. N. Marhaeni, "Pengaruh Evaluasi Diri terhadap Kemampuan Menulis Bahasa Inggris," e-learning Portal Univ. Pendidik. Ganesha, 
2008.

[10] N. M. Ratminingsih, A. A. I. N. Marhaeni, and L. P. D. Vigayanti, "Self-Assessment: The Effect on Students' Independence and Writing Competence," Int. J. Instr., vol. 11, no. 3, pp. 277-290, 2018, [Online]. Available: https://doi.org/10.12973/iji.2018.11320a.

[11] Z. Yan, "Self-assessment in the Process of Selfregulated Learning and its Relationship with Academic Achievement," Assess. Eval. High. Educ., vol. 45, no. 2, pp. 224-238, 2020, [Online]. Available: https://doi.org/10.1080/02602938.2019.1629390

[12] A. N. Stavros, "The Impact of Paper Based, Computer Based and Mobile Based SelfAssessment on Students' Science Motivation and Achievement," J. Comput. Hum. Behav., vol. 55, pp. 1241-1248, 2016.

[13] R. Kustijono, B. Jatmiko, and M. Ibrahim, "The Effect of Science Attitude towards Science Process Skills in Basic Physics Practicum by Using Peer Model," Int. J. Geomate, vol. 15, no. 50, pp. 82-87, 2018, [Online]. Available: https://doi.org/10.21660/2018.50.

[14] E. Panadero, D. Garcia, and J. Fraile, "SelfAssessment for Learning in Vocational Education and Training," Springer Handb. Vocat. Educ. Train., pp. 1359-1370, 2018, [Online]. Available: https://doi.org/10.1007/978-3-319-94532-3_85.

[15] A. Papanthymou and M. Darra, "Student SelfAssessment in Higher Education and Professional Training," Eur. J. Educ. Stud., vol. 6, no. 3, pp. 183-198, 2019, doi: 10.5281/zenodo.3250341.

[16] S. Lisnawati and S. Halimah, "Pengaruh SelfAssessment terhadap Hasil Belajar Penelitian Tindakan Kelas dan Penulisan Artikel pada Bidang Pendidikan Agama Islam," J. Pendidik. Islam, vol. 9, no. 2, pp. 195-210, 2018, doi: 10.24042/atjpi.v9i2.3627. 